\title{
Maryann Feldman: Recipient of the 2013 Global Award for Entrepreneurship Research
}

\author{
Mark Lorenzen · Bo Carlsson
}

Accepted: 24 February 2014/Published online: 20 March 2014

(C) The Author(s) 2014. This article is published with open access at Springerlink.com

\begin{abstract}
This article reviews the scientific contributions of the 2013 recipient of the Global Award for Entrepreneurship Research, Maryann Feldman, Heninger Distinguished Professor in the Department of Public Policy at the University of North Carolina. Maryann Feldman is well known for her contributions to the study of the geography of innovation. A central focus of her work is on the role of entrepreneurial activity in the formation of regional industry clusters. She has studied entrepreneurial events involving both individuals and teams and the role of knowledge spillovers and finance in geographical clustering. She has also addressed other important aspects of contemporary entrepreneurship research, such as how academic entrepreneurship is influenced by intellectual property rights and modes of finance and how hightechnology entrepreneurship aligns with public policy and the geography of innovation. The most significant impact of Maryann Feldman's scientific output lies in research on firm location, inter-firm knowledge
\end{abstract}

\section{Lorenzen}

DRUID, Department of Innovation and Organizational Economics (INO), Copenhagen Business School,

Kilevej 14A, 3, 2000 Frederiksberg, Denmark

e-mail: ml.ino@cbs.dk

B. Carlsson $(\bowtie)$

Department of Economics, Weatherhead School of Management, Case Western Reserve University, Cleveland, OH, USA

e-mail: Bo.Carlsson@case.edu spillovers, and clusters/regional development. Her research addresses macro aspects of industry evolution, micro-level aspects of firm strategy and organization, as well as meso-level aspects of institutions, infrastructures, and policy. The Global Award consists of 100,000 euro and a statuette by the internationally renowned Swedish sculptor Carl Milles.

Keywords Global Award · Entrepreneurship · Industry clusters · Regional development . Geography of innovation

JEL Classifications $\quad \mathrm{L} 2 \cdot \mathrm{L} 26 \cdot \mathrm{L} 5 \cdot \mathrm{M} 13 \cdot \mathrm{O} 3$

\section{Introduction}

The 2013 Global Award for Entrepreneurship Research has been awarded to Professor Maryann Feldman, Heninger Distinguished Professor in the Department of Public Policy at the University of North Carolina.

Professor Feldman is awarded for her important contributions in several areas of entrepreneurship research. She is well known for her contributions to the field of geography of innovation. A central focus of her work is on the role of entrepreneurial activity in the formation of regional industry clusters. She has made significant contributions to our understanding of innovation, commercialization of academic research, and factors promoting technological 
change and economic growth with particular emphasis on the regional dimension. In her research, Feldman has studied a variety of industries such as the pharmaceutical and biotech sector, investigating academic entrepreneurs and university-industry relations, intellectual property rights, and high-technology entrepreneurship.

Through her diverse, inventive, and often agendasetting work, Maryann Feldman has contributed significantly to entrepreneurship research. Spanning over several well-established as well as emerging themes in entrepreneurship research and often exploring their interdependencies, Maryann Feldman's work addresses individual entrepreneurs, the SMEs and universities they operate in, and the institutional and infrastructural contexts they co-evolve with at the regional, national and sectoral level.

Maryann Feldman's empirical and theoretical contributions have had substantial impact on entrepreneurship scholars as well as their colleagues in economics, management, and economic geography. Professor Feldman's contributions are of high quality and encompass an impressive output of conceptually sound, empirically thorough, and technically sophisticated papers in highly ranked journals.

Her work has also had a significant impact on policy. She has testified before the United States Congress on issues related to innovation and entrepreneurship and consulted with local governments and entrepreneurial organizations on strategy.

\section{Main contributions}

Maryann Feldman is a remarkably productive scholar whose work spans several sub-disciplines related to entrepreneurship. Whereas most entrepreneurship scholars focus on a single theme, Maryann Feldman's work has spanned a range of central issues. Her scientific output has encompassed some classic themes in entrepreneurship research: individuals and teams, finance, spillovers, and geographical clustering. In addition, she has addressed important aspects of contemporary issues in entrepreneurship research, such as academic entrepreneurs, university-industry relations, intellectual property rights, and high-technology entrepreneurship (in particular, within biotech but also pertaining to the Internet and optical science).
An important and distinctive feature of her work is that she integrates these themes in various subdisciplines into her research. For example, she has investigated the interrelationships between entrepreneurial events and clustering and regional development, discussed how academic entrepreneurship is influenced by intellectual property rights and modes of finance, and examined how high-technology entrepreneurship aligns with public policy and the geography of innovation. This is an accomplishment unique to an entrepreneurship scholar.

\subsection{Location, knowledge spillovers, industry clusters, and regional development}

The most significant impact of Maryann Feldman's scientific output lies in research on firm location, interfirm knowledge spillovers, cluster formation, and regional development. While other entrepreneurship scholars have explored the geographic aspects of entrepreneurship, Maryann Feldman's work has investigated the geographic dimension in greater depth, examining both how different industries and technologies expand across geographical space and how entrepreneurship unfolds within particular geographical localities. Many of Maryann Feldman's publications in this field address not only macro aspects of industry evolution but also micro-level aspects of firm strategy and organization, as well as meso-level aspects of institutions, infrastructures, and policy.

Maryann Feldman's most cited work is 'R\&D spillovers and the geography of innovation and production', co-authored with David Audretsch and published in the American Economic Review in 1996a. This paper addresses a fundamental controversy in economic geography: Whether geographical clustering of entrepreneurial activities is due to inter-firm knowledge spillovers rather than other external scale economies. The authors found that industries in which knowledge spillovers are prevalent-that is, where industry R\&D, university research, and skilled labor are particularly important-have a greater propensity for innovative activity to cluster than industries where knowledge externalities are less important.

Another paper co-authored with David Audretsch, 'Innovation in cities: Science-based diversity, specialization and localized competition' (in European Economic Review, 1999) addresses another key controversy in economic geography: The question of 
whether innovation is promoted by regional specialization or diversity. Focusing on small entrepreneurial firms and using the US Small Business Administration's Innovation Data Base, this paper suggests that diversity is more conducive to innovation than specialization. A third paper by Maryann Feldman and David Audretsch, the 1996b 'Innovative clusters and the industry life cycle' in the Review of Industrial Organization connects the problem of geographical agglomeration of entrepreneurial activity to the issue of industry life cycles, showing that clustering is more important for industries in early, innovation-intense stages. In collaboration with David Audretsch as well as Zoltan Acs, Maryann Feldman has published two papers on small entrepreneurial firms as recipients of R\&D spillovers from larger firms and universities and larger corporations: 'R\&D spillovers and recipient firm size' published in the Review of Economics \& Statistics (1994a) and 'R\&D Spillovers and Innovative Activity', published in 1994b in Managerial \& Decision Economics.

Maryann Feldman has also published a range of single-authored articles on the fundamentals of the geography of innovation: 'An examination of the geography of innovation' in Industrial \& Corporate Change (1993), 'Knowledge Complementarity and Innovation, in Small Business Economics (1994c), 'The new economics of innovation, spillovers and agglomeration: A review of empirical studies' in Economics of Innovation \& New Technology (1999; this literature review of the field is often cited), and 'The internet revolution and the geography of innovation' in International Social Science Journal (2002). Her article in Industrial and Corporate Change co-authored with Barak Aharonson and Joel Baum 'Desperately seeking spillovers? Increasing returns, industrial organization and the location of new entrants in geographic and technological space' (2007) further explores aspects of the geography of innovation relevant to entrepreneurship research, namely the strategy and organization of new entrants.

Another of Maryann Feldman's collaborations with high impact on the community researching location, knowledge spillovers, and clusters is that with Janet Bercovitz. Following up on Maryann Feldman's paper in Industrial and Corporate Change, 'The entrepreneurial event revisited: Firm formation in a regional context' (2001), their collaboration yielded the 2005 paper in Regional Studies, 'Creating a cluster while building a firm: Entrepreneurs and the formation of industrial clusters', which was successful in leveraging case studies in building a theory of entrepreneurship in clusters. More recently, this collaboration has also produced a paper that delves even further into the micro-level entrepreneurial processes at work in clusters: 'The mechanisms of collaboration in inventive teams: Composition, social networks, and geography' (in Research Policy, 2011).

Maryann Feldman is one of the leading scholars in the burgeoning research field addressing industrial clusters. Several of her co-authored publications in this field have been influential and are highly cited. This is true for her 1994 joint paper with Richard Florida, exploring the impact on innovation by a cluster's technological infrastructure (in the form of supporting industries, specialized public and private $\mathrm{R} \& \mathrm{D}$, and knowledge-intensive business services). The paper, 'The geographic sources of innovation: Technological infrastructure and product innovation in the United States', was published in Annals of the Association of American Geographers (1994). Issues pertaining to promoting high-technology entrepreneurship in clusters were explored in two papers coauthored with Johanna Francis, 'Homegrown solutions: Fostering cluster formation' in Economic Development Quarterly (2004) and 'Fortune favours the prepared region: The case of entrepreneurship and the capitol region biotechnology cluster' in European Planning Studies (2003). Later papers on the same issue encompass the 2005 Research Policy paper written with Roger Martin 'Constructing jurisdictional advantage', the 2008 European Planning Studies paper written with Nichola Lowe, 'Consensus from controversy: Cambridge's biosafety ordinance and the anchoring of the biotech industry', and the 2010 Review of Policy Research paper written with Gil Avnimelech, 'Regional corporate spawning and the role of homegrown companies.'

While examining the fundamental and long-standing issues related to firm location, knowledge spillovers, cluster formation, and regional development, Maryann Feldman has also kept a keen eye on another topical issue in entrepreneurship research: high-technology entrepreneurship. Starting with her 1996 paper in Small Business Economics, 'Geography and regional economic development: The role of technology-based small and medium sized firms', she has given particular attention to entrepreneurship in the 
pharmaceutical, biotech, and optical industries. Her empirical investigation of high-technology industries can be found throughout her scholarship, but the papers 'Initial Advantage: the origins of the geographic concentrations of the pharmaceutical industry in the Mid-Atlantic region' (written with Yda Schreuder, in Industrial and Corporate Change, 1996), 'The location dynamics of the US biotech industry: Knowledge externalities and the anchor hypothesis' (in Industry and Innovation, 2003a), and 'Under the lens: The geography of optical science as an emerging industry' (with Iryna Lendel, in Economic Geography, 2010) are examples of empirical papers on hightechnology industries.

Maryann Feldman has also authored and edited a range of highly successful books in the field of location, spillovers, and clusters/regional development. Her 1994a major opus The Geography of Innovation summarized her early research. Published by Kluwer, the book remains a key reference in the field. Another highly successful book project is the 2000 Oxford Handbook of Economic Geography edited with Gordon Clark and Meric Gertler. Addressing issues of geography and clustering as well as of academic entrepreneurs and university-industry relations, the Handbook has become very popular among scholars in economics, management, entrepreneurship, as well as economic geography. More recently, Maryann Feldman has edited (with Nadine Massard) Institutions and Systems in the Geography of Innovation (published in 2002 by Kluwer), (with Pontus Braunerhjelm) Cluster genesis: Technology-based industrial development (published in 2006 by Oxford University Press), and (with Harald Bathelt and Dieter F. Kogler) Beyond Territory: Dynamic Geographies of Knowledge Creation and Innovation, (published by Routledge in 2011).

Maryann Feldman's research within the field of location, knowledge spillovers, industry clusters, and regional development has made a significant contribution to our understanding of the role and nature of technological spillovers in the formation and growth of industry clusters, as well as the geographic dimensions of spillovers. Specifically, her publications provided early empirical testing of the claimed importance of localized knowledge spillovers as well as regional diversity: Her 1996 and 1999 papers with David Audretsch remain the most highly cited papers on these phenomena. More generally, Maryann
Feldman's research on the geography of innovation has inspired a thriving international community researching some of this agenda's main themes. These include the incidence of geographical clustering of innovation activities (for example, the 'Scandinavian school' on localized learning), local knowledge spillovers (such as the geography of 'buzz'), localized entrepreneurial activity (including the 2011 recipient of the Global Award for Entrepreneurship Research, the late Steven Klepper's work), and the geographical reach of innovation linkages (most notably, recent work on information pipelines and cluster connectivity). The geography of innovation is now a regular subject area under the Academy of Management's Strategy division and is addressed annually in the DRUID Society conferences.

\subsection{Academic entrepreneurs and university- industry relations}

The second major field in which Maryann Feldman has had a high impact is that of academic entrepreneurs and university-industry relations. In this field, her collaboration with David Audretsch has also been highly successful. Addressing Adam Jaffe's classic 1989 paper in the American Economic Review, Maryann Feldman's 1992 paper in the same journal written with David Audretsch and Zoltan Acs, 'Real effects of academic research: Comment', demonstrated that Jaffe's claims about knowledge spillovers from university research (based on a patent measure) could be supported using a direct measure for innovation (based on data from the US Small Business Administration). This paper strengthened the robustness of Jaffe's claims while boosting the scope for future empirical research into university-industry relations. Two later papers written with David Audretsch do not explore data, but instead take stock of the extant theoretical and empirical research pertaining to university-industry relations: 'Small-firm strategic research partnerships: The case of biotechnology', published in Technology Analysis \& Strategic Management in 2003 and 'The economics of science and technology' (also written with Barry Bozeman, Kathryn Combs, Albert Link, Donald Siegel, Paula Stephan, Gregory Tassey, and Charles Wessner), published in the Journal of Technology Transfer in 2002. 
Maryann Feldman's research collaboration with Janet Bercovitz has been particularly fruitful in examining academic entrepreneurship and university-industry relations. For example, the 2007 Research Policy paper 'Fishing upstream: Firm innovation strategy and university research alliances' explores managers' incentives for engaging with universities. The 2005 Journal of Technology Transfer paper 'Entrepreneurial universities and technology transfer: A conceptual framework for understanding knowledge-based economic development' theorizes university-industry relations from the viewpoint of universities - an exercise that to some extent was initiated in the paper (also written with Irwin Feller and Richard Burton) 'Organizational structure as a determinant of academic patent and licensing behavior: An exploratory of Duke, Johns Hopkins, and Pennsylvania State Universities' (Journal of Technology Transfer, 2001) and the 2002 Research Management Review paper (with the same co-authors) 'The state of practice of university technololgy transfer activities.' However, of Maryann Feldman's and Janet Bercovitz' joint research, two papers that empirically explore the incentives related to academic entrepreneurship stand out in terms of scientific impact. Their 2002 paper (written with Irwin Feller) in Management Science 'Equity and the technology transfer strategies of American research universities' demonstrates that while equity plays an important role as a technology transfer mechanism in US universities, its use is contingent upon university types, extant licensing practices, and the design of technology transfer offices. Another important joint paper, 'Academic entrepreneurs: Organizational change at the individual level', was published in Organization Science in 2008. Examining a large number of faculty members and demonstrating that their social environment and norms (as exhibited by leaders and peers) significantly influences their participation in academic entrepreneurship, this paper has become a key reference in academic entrepreneurship. This theme was also explored in a paper (with Nichola Lowe) published the same year in Cambridge Journal of Regions, Economics and Society, 'Constructing entrepreneurial advantage: Consensus building, technological uncertainty, and emerging industries'.

\subsection{Connections to other themes within entrepreneurship research}

As mentioned, many of Maryann Feldman's publications within the two major fields outlined above also connect to some classic themes in entrepreneurship research. It is beyond the scope of this review to discuss all the nexuses in Maryann Feldman's research where she integrates classic themes in entrepreneurship research into issues pertaining to location/ spillovers/clusters and academia/university, but a few examples are worth mentioning.

A range of Maryann Feldman's publications examine individuals and teams in entrepreneurship in substantial depth. The 2001 paper in Industrial and Corporate Change, 'The entrepreneurial event revisited: Firm formation in a regional context' and the 2005 paper in Regional Studies, 'Creating a cluster while building a firm: Entrepreneurs and the formation of industrial clusters', both go into depth with understanding how a cluster's supporting infrastructure may arise when pioneering individual entrepreneurs adapt to crises. The two papers 'Academic entrepreneurs: Organizational change at the individual level' (Organization Science, 2008) and 'The mechanisms of collaboration in inventive teams: Composition, social networks, and geography' (Research Policy, 2011) both constitute an advanced exploration of collaboration and organizational change at the level of individuals and teams.

A range of Maryann Feldman's most noteworthy publications also examine the importance of intellectual property rights and modes of finance-for example, the 2002 Management Science paper 'Equity and the technology transfer strategies of American research universities', the 2001 Journal of Technology Transfer paper 'Organizational structure as a determinant of academic patent and licensing behavior: An exploratory study of Duke, Johns Hopkins, and Pennsylvania State Universities', and a 2009 paper in the Journal of Economics \& Management Strategy (written with Timothy Simcoe and Stuart Graham), 'Competing on standards? Entrepreneurship, intellectual property, and platform technologies'. This latter paper demonstrates that while small entrepreneurial firms benefit from open standards (lowering entry barriers), they also pursue aggressive IP strategies that may undermine the openness of such standards. 


\subsection{Public policy}

Maryann Feldman has made significant contributions by critically assessing the scope for public policy in the field of academic entrepreneurship and universityindustry relations. Her most noteworthy publications in this area are the papers written with Maryellen Kelly, 'The ex ante assessment of knowledge spillovers: Government R\&D policy, economic incentives and private firm behavior' (in Research Policy, 2006), 'Leveraging research and development: Assessing the impact of the U.S. advanced technology program' (in Small Business Economics, 2003), and 'How states augment the capabilities of technology-pioneering firms' (in Growth and Change, 2002). This stream of Maryann Feldman's research also encompasses a book chapter published by Cambridge University Press (in a 2003b anthology edited by David Hart), as well as papers in Annales D'Économie et de Statistique (1998, with Frank Lichtenberg) and Industry and Innovation (2006, with Meric Gertler and David Wolfe).

A special feature in Maryann Feldman's research on public policy has been her efforts to elicit lessons from the case of the Johns Hopkins University, where she earlier held the position of Policy Director. Even if narrow in scope, these papers have been well-cited: The 1994b Economic Development Quarterly paper 'The University and economic development: The case of Johns Hopkins University and Baltimore', the 2003 Industry and Innovation paper 'Research universities and local economic development: Lessons from the history of the Johns Hopkins University', and the 2004 Minerva paper 'Truth for its own sake: academic culture and technology transfer at Johns Hopkins University' (both written with Pierre Desrochers).

In the research field of academic entrepreneurship and university-industry relations, Maryann Feldman has also kept an eye on high-technology industries, as evidenced in her 2000 Journal of Comparative Policy Analysis paper 'Where science comes to life: university bioscience, commercial spin-offs, and regional economic development' and her 2001 Entrepreneurship \& Regional Development paper (written with Cynthia Ronzio) 'Closing the innovative loop: moving from the laboratory to the shop floor in biotechnology manufacturing.'

Finally, it should be noted that Maryann Feldman has functioned as editor of research on academic entrepreneurship and university-industry relations:
With Albert Link, she edited Innovation Policy in the Knowledge-based Economy (published by Kluwer in 2001) and with Magnus Gulbrandsen and David Mowery, she edited a special section of Research Policy in 2011 on 'Heterogeneity and universityindustry relations'.

\section{Conclusions}

A highly productive entrepreneurship scholar, Maryann Feldman has pursued important themes across different research disciplines. A central idea in her research is the fundamental role of innovation and entrepreneurial activity in regional economic growth. In particular, her work has pursued the intricate interplays between entrepreneurship, geographical clustering, and higher education. Demonstrating that universities generate both human resources and entrepreneurial opportunities, Maryann Feldman's work has shown that universities are central to the geographical configuration of high-technology industries. Not only her findings but also her research method have inspired a broad range of scholars to follow her example in spanning traditional scholarly boundaries to the significant benefit of future entrepreneurship research as well as research in management, innovation studies, and economic geography.

Open Access This article is distributed under the terms of the Creative Commons Attribution License which permits any use, distribution, and reproduction in any medium, provided the original author(s) and the source are credited.

\section{References}

Acs, Z., Audretsch, D. B., \& Feldman, M. (1992). Real effects of academic research: Comment. American Economic Review, 82(1), 363.

Acs, Z., Audretsch, D., \& Feldman, M. (1994a). R\&D spillovers and recipient firm size. Review of Economics and Statistics, $76(2), 336$.

Acs, Z., Audretsch, D., \& Feldman, M. (1994b). R\&D spillovers and innovative activity. Managerial and Decision Economics, 15(2), 131-138.

Aharonson, B. S., Baum, J. A. C., \& Feldman, M. (2007). Desperately seeking spillovers? Increasing returns, industrial organization and the location of new entrants in geographic and technological space. Industrial and Corporate Change, 16(1), 89-130. 
Audretsch, D., Bozeman, B., Combs, K. L., Feldman, I., Link, A. L., Siegel, D. S., et al. (2002). The economics of science and technology. Journal of Technology Transfer, 27(2), 155-203.

Audretsch, D., \& Feldman, M. (1996a). R\&D spillovers and the geography of innovation and production. American Economic Review, 86(3), 630-640.

Audretsch, D., \& Feldman, M. (1996b). Innovative clusters and the industry life cycle. Review of Industrial Organization, 11(2), 253-273.

Audretsch, D., \& Feldman, M. (2003). Small-firm strategic research partnerships: The case of biotechnology. Technology Analysis \& Strategic Management, 15(2), 273.

Avnimelech, G., \& Feldman, M. (2010). Regional corporate spawning and the role of homegrown companies. Review of Policy Research, 27(4), 475-489.

Bathelt, H., Feldman, M., \& Kogler, D. (Eds.). (2011). Beyond territory: Dynamic geographies of knowledge creation, diffusion, and innovation. New York: Routledge.

Bercovitz, J., \& Feldman, M. (2005). Entrepreneurial universities and technology transfer: A conceptual framework for understanding knowledge-based economic development. Journal of Technology Transfer, 31(1), 175-188.

Bercovitz, J., \& Feldman, M. (2007). Fishing upstream: Firm innovation strategy and university research alliances. Research Policy, 36(7), 930-948.

Bercovitz, J., \& Feldman, M. (2008). Academic entrepreneurs: Organizational change at the individual level. Organization Science, 19(1), 69-89.

Bercovitz, J., \& Feldman, M. (2011). The mechanisms of collaboration in inventive teams: Composition, social networks, and geography. Research Policy, 40(1), 81-93.

Bercovitz, J., Feldman, M., Feller, I., \& Burton, R. (2001). Organizational structure as a determinant of academic patent and licensing behavior: An exploratory study of Duke, Johns Hopkins, and Pennsylvania State Universities. Journal of Technology Transfer, 26(1-2), 21-35.

Braunerhjelm, P., \& Feldman, M. (Eds.). (2006). Cluster genesis: Technology-based industrial development. Oxford: OUP.

Clark, G., Feldman, M., \& Gertler, M. (Eds.). (2000). Oxford handbook of economic geography. Oxford: OUP.

Feldman, M. (1993). An examination of the geography of innovation. Industrial and Corporate Change, 2(3), 451-470.

Feldman, M. (1994a). The geography of innovation. Dordrecht: Kluwer.

Feldman, M. (1994b). The university and economic development: The case of Johns Hopkins University and Baltimore. Economic Development Quarterly, 8(1), 67.

Feldman, M. (1994c). Knowledge complementarity and innovation. Small Business Economics, 6(5), 363-372.

Feldman, M. (1996). Geography and regional economic development: The role of technology-based small and medium sized firms. Small Business Economics, 8, 71-74.

Feldman, M. (1999). The new economics of innovation, spillovers and agglomeration: A review of empirical studies. Economics of Innovation and New Technology, 8(1/2), 5.

Feldman, M. (2000). Where science comes to life: University bioscience, commercial spin-offs, and regional economic development. Journal of Comparative Policy Analysis, 2(3), 345-361.

Feldman, M. (2001). The entrepreneurial event revisited: Firm formation in a regional context. Industrial and Corporate Change, 10(4), 861-891.

Feldman, M. (2002). The Internet revolution and the geography of innovation. International Social Science Journal, 54(171), 47.

Feldman, M. (2003a). The location dynamics of the US biotech industry: Knowledge externalities and the anchor hypothesis. Industry and Innovation, 10(3), 311-328.

Feldman, M. (2003b). Entrepreneurship and American research universities: Evolution in technology transfer. In David. Hart (Ed.), The emergence of entrepreneurship policy: Governance, start-ups, and growth in the U.S. knowledge economy (pp. 92-112). Cambridge: Cambridge University Press.

Feldman, M., \& Audretsch, D. (1999). Innovation in cities: Science-based diversity, specialization and localized competition. European Economic Review, 43(2), 409-429.

Feldman, M., \& Desrochers, P. (2003). Research universities and local economic development: Lessons from the history of the Johns Hopkins University. Industry and Innovation, 10(1), 5-24.

Feldman, M., \& Desrochers, P. (2004). Truth for its own sake: Academic culture and technology transfer at Johns Hopkins University. Minerva, 42(2), 105-126.

Feldman, M., Feller, I., \& Bercovitz, J. (2002). Equity and the technology transfer strategies of American research universities. Management Science, 48, 105-121.

Feldman, M., \& Florida, R. (1994). The geographic sources of innovation: Technological infrastructure and product innovation in the United States. Annals of the Association of American Geographers, 84(2), 210.

Feldman, M., \& Francis, J. (2003). Fortune favours the prepared region: The case of entrepreneurship and the capitol region biotechnology cluster. European Planning Studies, 11(7), 765-788.

Feldman, M., \& Francis, J. L. (2004). Homegrown solutions: Fostering cluster formation. Economic Development Quarterly, 18(2), 127-137.

Feldman, M., Francis, J., \& Bercovitz, J. (2005). Creating a cluster while building a firm: Entrepreneurs and the formation of industrial clusters. Regional Studies, 39(1), 129-141.

Feldman, M., Gertler, M., \& Wolfe, D. (2006). University technology transfer and national systems of innovation: Introduction to the special issue of industry and innovation. Industry and Innovation, 13(4), 359-370.

Feldman, M., \& Kelley, M. (2002). How states augment the capabilities of technology-pioneering firms. Growth and Change, 33(2), 173.

Feldman, M., \& Kelley, M. (2003). Leveraging research and development: Assessing the impact of the U.S. Advanced Technology Program. Small Business Economics, 20(2), 153.

Feldman, M., \& Kelley, R. (2006). The ex ante assessment of knowledge spillovers: Government R\&D policy, economic incentives and private firm behavior. Research Policy, 35(10), 1509-1521. 
Feldman, M., \& Lendel, I. (2010). Under the lens: The geography of optical science as an emerging industry. Economic Geography, 86(2), 147-171.

Feldman, M., \& Lichtenberg, F. (1998). The interaction between public and private R\&D investment: Cross-country evidence from the European Community's R\&D information service. Annales D'Économie et de Statistique, 49(50), 199-222.

Feldman, M., \& Link, A. (Eds.). (2001). Innovation policy in the knowledge-based economy. Dordrecht: Kluwer.

Feldman, M., \& Lowe, N. (2008). Consensus from controversy: Cambridge's biosafety ordinance and the anchoring of the biotech industry. European Planning Studies, 16(3), 395-410.

Feldman, M., \& Martin, R. (2005). Constructing jurisdictional advantage. Research Policy, 34(8), 1235-1249.

Feldman, M., \& Massard, N. (Eds.). (2002). Institutions and systems in the geography of innovation. Dordrecht: Kluwer.

Feldman, M., \& Ronzio, C. R. (2001). Closing the innovative loop: Moving from the laboratory to the shop floor in biotechnology manufacturing. Entrepreneurship \& Regional Development, 13(1), 1-16.

Feldman, F., \& Schreuder, Y. (1996). Initial advantage: The origins of the geographic concentrations of the pharmaceutical industry in the mid-Atlantic region. Industrial and Corporate Change, 5(3), 839-862.

Feller, I., Feldman, M., \& Bercovitz, J. (2002). The state of practice of university technology transfer activities. Research Management Review, 12(2), 8-16.

Gulbrandsen, M., Mowery, D., \& Feldman, M. (2011). Introduction to the special section: Heterogeneity and university-industry relations. Research Policy, 40(1), 1-5.

Lowe, N., \& Feldman, M. (2008). Constructing entrepreneurial advantage: Consensus building, technological uncertainty and emerging industries. Cambridge Journal of Regions, Economics and Society, 1(2), 265-284.

Simcoe, T. S., Graham, S. J. H., \& Feldman, M. (2009). Competing on standards? Entrepreneurship, intellectual property, and platform technologies. Journal of Economics and Management Strategy, 18(3), 775-816. 